\title{
Implementation Learning Book of Teaching Indonesian to Speaker from Other Language (TISOL) based on Javanese Culture using Scientific Approach: Study in Central Java, East Java, and Yogyakarta
}

\author{
K Saddhono ${ }^{1}$, R Suhita ${ }^{2}$, M Rohmadi ${ }^{3}$, B W Setyawan ${ }^{4}$ \\ ${ }_{1,2,3,4}$ Universitas Sebelas Maret Surakarta \\ 1kundharu.uns@gmail.com, ${ }^{2}$ raheni_suhita@yahoo.com, ${ }^{3}$ rohmadi_dbe@yahoo.com, \\ bagusws93@gmail.com
}

\begin{abstract}
Need of TISOL learning have been concerned, but until now there aren't a based curriculum. Therefore, learning material of TISOL learning which used still be separated with culture integration. This research have aim to develop learning material based on Javanese culture to foreign student in Central Java, East Java, and Yogyakarta. The newest issues of this study is integration of Javanese culture to TISOL learning material using thematic-integrative approach. This research is Research and Development (R\&D) which conducted in various TISOL institutions in Central Java, East Java, and Yogyakarta. Product of this research is learning materials based on Javanese culture. Learning materials based on Javanese culture from this research have excellent point in every theme which explain some of Javanese culture unsure, so that the TISOL student have a comprehensive illustration about Javanese culture. Themes which develop in this learning material that are, (1) friendship, (2) Javanese new year, (3) Javanese traditional costume, (4) Javanese culinary, (5) Javanese house and environment, (6) praying place, (7) Javanese weeding, (8) Mall and traditional market, (9) transportation, (10) Javanese dance, (11) Javanese traditional playing, and (12) Javanese music.
\end{abstract}

Keywords: TISOL, Learning Materials, Javanese Culture, Scientific Approach, Impelementation

\section{INTRODUCTION}

Language in human life has a fundamental role. It is a set of arbitrary oral sound and has meaning. It mainly functions as a means of communication. Communication event always relates to two contexts, namely language and cultural contexts. Language context refers to utterance context or situational context, probably including aspects of participant identity, time, and place of communication event, utterance topic, and utterance purpose [1]. Cultural context indicates that each language user in conducting social interaction or communication is always patterned by their own culture [2]. It is in relation to interaction pattern among speakers and surrounding nature. The interaction pattern in further explanation contains language aspects in which if it is translated, it will have deep meaning and can be used as introduction material to students, in terms of domestic and foreign students. 
Foreign speaker students who study in Indonesia, must, at least, master Indonesian language as a second language. It is because of that language is used in educational field, as established in the Law Number 24 Year 2009 on flag, language, and national symbol. According to the Law Number 24 Year 2009, article 29, paragraph (1), Indonesian language is necessary to be used as a language instruction in national educations. By mastering Indonesian language, foreign students can more easily communicate in oral and written language, especially in learning process. Consequently, some higher educations with having students from outside Indonesia implement a Teaching Indonesia to Speakers of Other Language (TISOL) program. The TISOL program is implemented in many higher educations in Indonesia to give language tutoring and introduction for foreign students.

Before foreign students study intensively in their higher education, they need to be given a practice on indigenous language where the higher education is located in order to alleviate communication [3][5]. The number of foreign students in Central Java, East Java, and Yogyakarta increasingly grow and come from various countries. For example, foreign students in Universitas Sebelas Maret (UNS) Surakarta, Central Java were 191 students (source: UNS website, 2015). However, some TISOL institutions in Java and Bali islands uses different textbook [5]. The TISOL institution of Universitas Negeri Yogyakarta (UNY) has owned textbook compiled by the institution itself. Besides, TISOL learning material in Universitas Negeri Malang (UM) has been compiled in a TISOL book entitled "Living Indonesia" that is slight representative. However, it is lack of cultural aspect that support related materials.

As the situation above, it indicates that there is a need to develop culture-based TISOL e-book to bridge the need of introducing culture and increasing communication skill of TISOL students in Central Java, East Java, and Yogyakarta. Learning activities with a systematic and planned Javanese local culture-based e-booken courages TISOL students more ready and able to receive learning materials better [6][7]. The textbook developed is supported by videos of some Javanese local culture events to give Javanese language learners the initial knowledge as a second language. Besides, the learning process is also provided by handbooks for students and instructors.

Javanese culture is selected to be one of TISOL learning materials because it contains unique and different local values from one region to another [8]. Some elements such as arts, belief systems, traditional ceremonies, languages, and literatures in each region have differences [9]. This developmental research assignsa theme of Javanese culture due to its distinctiveness to be studied, investigated, and developed as a learning material integrated in Javanese language learning for foreign students. This also supports the adaptation process of foreign students while they live in Java and Bali in regard to Javanese language and culture that is dynamic and always abreast of the time [10].

The novelty of this research is the integration of Javanese culture in a TISOL learning material with using a scientific-integrative approach. This approach is selected to give foreign students more knowledge on language, culture and required knowledge for communication practice in real life [11]. Moreover, the research on integrating Javanese culture as a TISOL learning media is indirectly able to improve learning process and result. The learning material determined as research object also focuses on intermediate level foreign students. Therefore, learning a certain language as a second language for foreign students needs particular characteristic in terms of language skill level or foreign language learning level [12].

\section{RESEARCH METHOD}


This research was a developmental research, developing a local culture-based TISOL learning in Central Java, East Java, and Yogyakarta with a scientific thematic approach. There are stages of the research and development, but only four were applied, namely (1) preliminary study or exploration, (2) prototype development, (3) prototype testing, and (4) product dissemination. This research was set in TISOL institutions in Central Java, East Java, and Yogyakarta. The data were collected in regard to observing some higher educations in Central Java, East Java, and Yogyakarta with having a local culture-based TISOL program. They are obtained Universitas Gajah Mada (Yogyakarta), Universitas Negeri Yogyakarta (Yogyakarta), Universitas Sebelas Maret (Central Java), Universitas Negeri Semarang (Central Java), Universitas Negeri Malang (East Java), and Universitas Negeri Surabaya (East Java). Sampling technique utilized purposive sampling technique, to direct the selection of samples that were important and related to research subject [13]. This purposive sampling technique was considered as an extremely appropriate technique in a research with varied data. The content analysis was conducted to test the substance and effectiveness of local culture-based TISOL ebook, with thematic approach. A qualitative research was accounted to describe and explain participant perceptions, namely students, instructors, and TISOL organizers [14]. In expanding the study, this research carried out Focus Group Discussion (FGD) to develop the prototype model. Hence, triangulations in terms of theory, method, and informant review were employed. The triangulation of theory dealt with using some different theory perspectives to discuss the investigated problems in order to get more precise and reliable conclusion.

\section{RESULT AND DISCUSSION}

Javanese culture is assigned in the development of textbook is due to some reasons, namely Javanese culture that has unique local values, and Javanese culture that is different from one region to others. Hence, it is interesting to study, investigate and develop Javanese culture. The distinctiveness of Javanese culture will enrich the adaptation process of foreign students during their living in Central Java, East Java, Special Region of Yogyakarta, and will increase their interest to visit Java-related areas. The novelty of this research was the integration of Javanese culture in the TISOL learning material with using the thematic-integrative approach. This is conducted because of that some previous researches on innovative learning method were directly able to improve learning process and result [15]. Learning material to be selected as research subject was addressed to intermediate level foreign students. It is assumed that foreign students who learn Indonesian language are initially interested in Indonesian culture. Hence, the introduction of Indonesian culture is truly appropriate to be carried out at intermediate level in TISOL learning. One alternative is to design learning with a scientific-integrative approach by integrating the learning material of Javanese culture in Javanese language learning textbook for foreign speakers [16].

\subsection{Development of TISOL Textbook based on Local Wisdom}

One highlighted in the implementation of learning with textbook is the difficulty to encourage students in doing discussion for creating learning interaction. Consequently, the textbook development and revision are required to do, especially in terms of textbook structure, so the textbook is not only considered as a collection of pictures, videos or texts but also viewed as a collection of objects [21]. These objects, as proposed by Ratna Wardani, are texts, paragraphs, part of e-book, chapters, tables, pictures and others in which each object can 
represent a topic in a discussion. This will alleviate foreign students in TISOL learning to more recognize learning materials, especially the local wisdom-based one.

The innovation relates to framework model, which introduces an interaction model to an textbook. The model developed will become a platform for the development of textbook with more dynamic features in regards to connecting TISOL students with a dynamic learning environment, especially sociocultural environment of the surrounding community. In this platform, it is possible to develop textbook with adding a personal learning feature [22]. Meanwhile, to illustrate the interaction model proposed, a scenario is deployed to show how the interaction model is implemented in a local wisdom-based TISOL textbook in order to increase collaboration and effectiveness aspects of learning process using textbook developed. Moreover, the strength of this local culture-based TISOL textbook model is to be able to support explanatory learning model, through its interaction model, so that enable users, TISOL students and instructors, in learning TISOL activities, such as discussing or sharing information, reading book, and other literatures.

After conducting a set of tests, this model is proven in the ability to improve reading and learning motivation since the textbook contextual room allows to use social media appropriate with the reading topic. The tests are conducted in some TISOL institutions, including Universitas Gajah Mada (Yogyakarta), Universitas Negeri Yogyakarta (Yogyakarta), Universitas Sebelas Maret (Central Java), Universitas Negeri Semarang (Central Java), Universitas Negeri Malang (East Java), and Universitas Negeri Surabaya (East Java). They indicate significant results, in which the grade of TISOL students in the material of reading skill improve as much as $30 \%$.

\subsection{Implemention of TISOL Textbook based Javanese Local Wisdom with Integrative Thematic Approach}

The diversity of TISOL learner background indicates the variation of specific learning objectives. However, the goal of Indonesian language learning for foreign speakers is generally to make learners master in using Indonesian language communicatively and pragmatically. In a consequence, to determine learning material requires general and specific teaching goals. One alternative for TISOL learners is by involving an aspect of Javanese culture integration in the learning material.

Through the culture-integrated learning, TISOL students will more recognize and love culture where they live in. They may feel to be given a role on enjoying those cultures [23]. The happy and warm feelings they have due to the feeling of being a part of culture. Moreover, they may learn other cultures where their friends come from. Hence, culture is clearly important to be taught, especially to TISOL students since local culture, especially Javanese art, Javanese costume, Javanese Song, Javanese traditional food, etc, contains some values that can be used by TISOL students as a reference for interacting with the surrounding community. These values are the representation of thought patterns, views, philosophy of the surrounding community. Thus, it indicates that local culture material in TISOL learning is definitely beneficial for foreign students in recognizing social and cultural background of the surrounding community deeply.

To formulate a thematic learning material used in the local culture-based textbook requires an innovation on instructor point of view in delivering materials subject to the interrelation of material and daily life oriented to Indonesian cultural wealth. Multicultural perspective in learning materials is able to do condensation to learner cultural experiences and point of views in mastering Indonesian language [24]. Thus, TISOL students are able to master Indonesian language appropriate with cultural contexts. 
In a consequence, learning materials in TISOL textbook need to have intercultural contexts. This has to compiled by taking account for some considerations, namely (1) learning materials that contain a direct instruction on mastering target culture materials; (2) learning materials that can be used as a clear and directive map to give an overview about a good structured program linguistically and culturally in which learners need to master it in a certain period of time; (3) learning materials that should become a sufficient source for various information and most suitable and useful activities in communicative and cultural competence achievements; (4) learning materials that should be able to become a source for learners to teach and give feedback one another; and (5) learning materials that should reflect a point of view and cultural system targets for being a reference for foreign students to consider culture of this country [25].

The implementation of the local culture-based textbook in TISOL learning can be conducted by using multicultural and intercultural approaches. It can be realized in some methods as proposed by Hudghes [26] that there are some alternative multicultural learning strategies in language/ second language learning as the followings.

- Comparison Method. Learning is started with delivering materials about one or more types of target culture that are absolutely different with student culture. After that, the discussion focuses on the reason of cultural differences that can result in cultural misunderstanding.

- Culture Assimilator. It is a short description of a critical incident (incidents that potentially result in misunderstanding) in an intercultural interaction enabling to be misunderstood by learners. In this technique, instructors give a description of the critical incident supported by some alternative explanations and their solutions. If student answer is wrong, have to try to search the right information by discussing it with other groups.

- Culture Capsule. This strategy is nearly similar to culture assimilator. Instructors give a presentation and explanation on main differences of Indonesian culture (target) and foreign culture (students') through audio-visual media. This presentation is also provided by some questions to enable discussion among students.

- Audiomotorunit or Total Physical Response. This technique is usually set in listening. Students are encouraged to do something appropriate with what they listen or see. As a result, they directly experience a certain cultural activity.

- Newspaper. Students is facilitated to compare some cultural aspects of theirs with Indonesian culture as illustrated in a newspaper. Some parts of newspaper will show many cultural differences, such as headlines, advertisement, editorial, and caricature.

- $\quad$ Projected Media. The use of film, documenter, slide, and filmstrips containing the cultural information will extremely attract student interest to learn some aspects of Indonesian culture (target). The use of video produced by learning while doing a journey will make learning more interactive.

- The cultural island. Instructors and students collectively change the class into a certain cultural setting by installing or putting a poster, picture, artefact, or music. This enables learners to "experience" life of a certain culture.

The implementation of the methods above can be carried out in various ways, by fitting goal and material characteristic learned by TISOL students in accordance with four language skills, which is listening, speaking, reading, and writing skills [27]. In reading skill, TISOL students are expected to know contents of a text and to be able to resume a text. In learning process, there are some steps carried out. First, pre activity refers to that instructors give the explanation about Central Java culture included by pictures. Second, whilst activity deals with students reading a text about dance from Central Java in terms of some activities. The first activity indicates that (1) students read a text well, (2) students answer questions in a textbook, 
(3) students gives opinion about dance in Central Java, and (4) students compile a list of difficult words from a text with searching its meaning in a dictionary.

\section{CONCLUSIONS}

A TISOL program is required to take by some foreign students who take educational program in Indonesia. It aims to train Indonesian language skill of foreign students useful for the communication among local communities. The development of a TISOL textbook based Javanese culture adjusted to teaching goals, student condition and local culture condition. The integration of Javanese culture material can support the language mastery of TISOL students. This is due to that in the material of the Javanese culture and values from Javanese culture, such as mutual cooperation, togetherness, being religious, and love environment as the representation of Javanese community characters. Thematic learning materials deployed in TISOL learning are directly objected to a certain theme. A theme of the Javanese culture is considered familiar because most regions Central Java, East Java, and Yogyakarta have this tradition. Consequently, it is indicated to be more effective of determining this tradition as TISOL learning material. The stage of implementing the TISOL textbook based on Javanese culture with the scientific thematic approach in TISOL learning involves some methods, namely Comparison Method, Culture Assimilator, Culture Capsule, Audiomotorunit or Total Physical Respon, Newspaper, Projected Media, and The Cultural Island. These methods may be varied in its implementation depending on the situation and condition of the class and teaching goal of TISOL program.

\section{REFERENCES}

[1]. Timmer, K., Christoffels, I. K., and Costa, A., 2019, On the flexibility of bilingual language control: The effect of language context. Bilingualism: Language and Cognition, 22(3), p.555-568.

[2]. Saddhono, K., 2018, Cultural and social change of foreign students in Indonesia: The influence of Javanese Culture in Teaching Indonesian to Speakers of Other Languages (TISOL), In IOP Conference Series: Earth and Environmental Science 126(1), p. 012091 IOP Publishing.

[3]. Zhao, A., et. All., 2013, Foreign Language Reading Anxiety: Chinese as a Foreign Language in the United States, The Modern Language Journal. 97(3), p. 764-778.

[4]. Kobayashi, Y., 2013, Europe versus Asia: foreign language education other than English in Japan's hogher education, Journal of Higher Education, 66 (3), p. 269-281.

[5]. Saddhono, K., 2015, Integrating Culture in Indonesian Language Learning for Foreign Speakers at Indonesian Universities, Journal of Language and Literature, 6(2), p.349-353.

[6]. Mouri, K., Uosaki, N., and Ogata, H., 2018, Learning Analytics for Supporting Seamless Language Learning using E-book with Ubiquitous Learning System, Journal of Educational Technology \& Society, 21(2), p.150-163.

[7]. Spirn, A. W., and Whiteside, A. B., 2014, The Promise and Problems of the Visual E-Book: Call for an Alliance between Authors and Librarians, Art Documentation: Journal of the Art Libraries Society of North America, 33(2), pp.206-226.

[8]. Sulaksono, D., Setyawan, B. W., and Saddhono, K., 2018, Javanese-Arabic Cultural Acculturation in Kethoprak Mesiran Performing Arts, In International Seminar on Recent Language, Literature, and Local Cultural Studies (BASA 2018), Atlantis Press.

[9]. Pramudita, K., and Rosnawati, R., 2019, Exploration of Javanese culture ethnomathematics based on geometry perspective. In Journal of Physics: Conference Series, 1200(1), p. 012002. IOP Publishing.

[10]. Smith, N. J. and Hefner, 2009, Language Shift, Gender, and Ideologies of Modernity in Central Java, Indonesia, Journal of Linguistic Anthropology, 19 (1), p.57-77. 
[11]. Saddhono, K., 2016, Teaching Indonesian As Foreign Language: Development Of Instructional Materials based Javanese Culture With Scientific-Thematic Approach, In Proceeding of the International Conference on Teacher Training and Education, 2(1), p. 583-593.

[12]. Kramsch, C., 2000, Second Language Acquistion, Applied Linguistics, and the Teaching of Foreign Language, The Modern Language Journal, 84 (3), p. 311-364.

[13]. Sutopo, 2002, Metode Penelitian Kualitatif, Surakarta: UNS Press.

[14]. Moleong, L. J., 2014, Metodologi Penelitian Kualitatif (EdisiRevisi). Bandung: PT Remaja Rosdakarya

[15]. Crompton, H., Grant, M. R., and Shraim, K. Y., 2018, Technologies to enhance and extend children's understanding of geometry: A configurative thematic synthesis of the literature, Journal of Educational Technology \& Society, 21(1), p.59-69.

[16]. Howard, G. R., 2016, We can't teach what we don't know: White teachers, multiracial schools. America: Teachers College Press.

[17]. Suryani, S. D., 2014, Tayub as a Symbolic Interaction Medium in Sedekah Bumi Ritual in Pati Regency, Harmonia: Journal of Arts Research and Education, 14(2), p.97-106.

[18]. Rachmawati, J. I., Warto, W., and Pitana, T. S., 2018, Selling Sacredness: Representation of Sedekah Gunung Ritual in Lencoh Village, Boyolali in New Media, Mozaik Humaniora, 18(2), p.188-200.

[19]. Hendro, E. P., 2018, Religiusitas Gunung Merapi, ENDOGAMI, 2(1), p.21-29.

[20]. Griyanti, H. E., Sunardi, S., and Warto, W., 2018, Digging The Traces of Islam in Baritan Tradition, International Journal of Multicultural and Multireligious Understanding, 5(3), p.5259.

[21]. Hwang, G. J., Tu, N. T., and Wang, X. M., 2018, Creating interactive E-books through learning by design: The impacts of guided peer-feedback on students' learning achievements and project outcomes in science courses. Journal of Educational Technology \& Society, 21(1), p.25-36.

[22]. Kohn, K., 2018, Worth the wait? Using past patterns to determine wait periods for e-books released after print, College \& Research Libraries, 79(1), p.35.

[23]. Matsumoto, Y. and Okamoto, S, 2003, The Contruction of Japanese Language and Culture in Teaching Japanese as a Foreign Language, Japanese Language and Literature Journal, 37 (1). p. 27-48.

[24]. Siegal, M. and Okamoto, S., 2003, Toward Reconceptualizing the Teaching and Learning of Gendered Speech Styles in Japanese as a Foreign Language, Japanese Language and Literature Journal, 37 (1), p.49-66.

[25]. Cortazzi, M. and Jin, L., 2018, Journeys of learning, Narrative and Metaphor in Education: Look Both Ways, 7(3).

[26]. Ballantyne, R., Hughes, K., Lee, J., Packer, J., and Sneddon, J., 2018, Visitors' values and environmental learning outcomes at wildlife attractions: Implications for interpretive practice, Tourism management, 64, p.190-201.

[27]. Saddhono, K., and Rohmadi, M., 2014, A Sociolinguistics Study on the Use of the Javanese Language in the Learning Process in Primary Schools in Surakarta, Central Java, Indonesia. International Education Studies, 7(6), p.25-30. 